\title{
Inhibitors of Cyclic-GMP Phosphodiesterase Alter Excitation of Limulus Ventral Photoreceptors in $\mathrm{Ca}^{2+}$-Dependent Fashion
}

\author{
Edwin C. Johnson ${ }^{1, a}$ and Peter M. O'Day² \\ 'Department of Physiology, Marshall University School of Medicine, Huntington, West Virginia 25755-9340 and \\ ${ }^{2}$ Institute of Neuroscience and Department of Biology, University of Oregon, Eugene, Oregon 97403-1254
}

\begin{abstract}
We have examined the hypothesis that $\mathrm{Ca}^{2+}$-dependent cyclic-GMP metabolism may play a role in visual transduction in Limulus photoreceptors. Although phosphoinositide hydrolysis is central to phototransduction and phosphoinositide-dependent $\mathrm{Ca}^{2+}$-mobilization seems to be required for transduction, the subsequent steps leading to ion channel gating (the immediate cause of excitation) are not understood. Channels normally opened in response to light can be opened in excised membrane patches by cGMP but not by $\mathrm{Ca}^{2+}$, suggesting that cGMP acts as a channel ligand in excitation.
\end{abstract}

Using phosphodiesterase inhibitors, we investigated whether changes in cGMP metabolism could affect excitation. We report that zaprinast and IBMX increased the amplitudes and retarded the kinetics of physiological light responses. These effects were maximal for brightest stimuli. The effects were markedly enhanced in low $\mathrm{Ca}^{2+}$ conditions. In contrast, excitation induced by direct $\mathbf{I P}_{3}$-injection and by direct $\mathrm{Ca}^{2+}$-injection were inhibited. These observations suggest that Pl-induced excitation is dependent on cGMP metabolism in a $\mathrm{Ca}^{2+}$-dependent manner, and they support the possibility that transduction involves modification of cGMP metabolism by $\mathrm{Ca}^{2+}$-release resulting from phosphoinositide hydrolysis.

[Key words: phototransduction, zaprinast, M\&B22948, cGMP phosphodiesterase, photoreceptor, Limulus, $\mathrm{Ca}^{2+}$, phosphoinositide, $I P_{3}$ cyclic-GMP]

Two intracellular second messenger systems, the phosphoinositide (PI) pathway and the cyclic-GMP (cGMP) pathway, appear to be important in light-induced excitation of Limulus photoreceptors (Brown et al., 1984b, 1987; Fein et al., 1984; Bacigalupo et al., 1990; Feng et al., 1991; Faddis and Brown, 1992, 1993; Inoue et al., 1992). The involvement of the PI pathway in invertebrate excitation is supported by several lines of evidence (Payne et al., 1988; Ranganathan et al., 1991; Hardie and Minke,

\footnotetext{
Received Apr. 14, 1995; revised May 30, 1995; accepted June 1, 1995

We gratefully acknowledge Toufik Sadat, Jamie Crona, and Linda Lloyd for experimental assistance. We also thank Drs. John Lisman, Juan Bacigalupo, Judith Eisen, Phyllis Robinson, Mark Gray-Keller, and Mark Simmons for helpful discussions and readings of the manuscript. Funding came from National Science Foundation BNS8812455 (to E.C.J.), National Institutes of Health EY09388 (to P.M.O.), and an American Heart Association, Oregon Affiliate grant (to P.M.O.).

Correspondence should be addressed to Peter M. O'Day, Institute of Neuroscience, University of Oregon, Eugene, OR 97403-1254.

aPresent address: Salk Institute Biotechnology/Industrial Associates, La Jolla, CA.

Copyright (C) 1995 Society for Neuroscience $0270-6474 / 95 / 156586-06 \$ 05.00 / 0$
}

1994) consistent with the idea that the following events occur in phototransduction. Activation of visual pigment, rhodopsin, by light activates a G-protein, stimulating hydrolysis of phosphatidylinositol 4,5-bisphosphate $\left(\mathrm{PIP}_{2}\right)$ by phospholipase $\mathrm{C}$; this creates cytosolic inositol 1,4,5-trisphosphate $\left(\mathrm{IP}_{3}\right)$, the trigger for mobilization of intracellular $\mathrm{Ca}^{2+}$ and elevation of [Ca $\left.{ }^{2+}{ }_{\mathrm{i}}\right]$. In Limulus photoreceptors, $\mathrm{Ca}^{2+}$-mobilization causes excitation by opening plasma membrane channels; however, the link between $\mathrm{Ca}^{2+}$ elevation and channel gating remains obscure.

Electrophysiological evidence implicates cGMP involvement in Limulus transduction (Johnson et al., 1986; Bacigalupo et al., 1991; Feng et al., 1991). The observation that light-activated channels are gated selectively by cGMP and not by $\mathrm{Ca}^{2+}(\mathrm{Ba}-$ cigalupo et al., 1991) points to cGMP as a channel ligand in transduction, supporting the notion that excitation is mediated by elevation of the cGMP concentration ( $[\mathrm{cGMP}]_{i}$ ) near the channels. Light-induced elevation of $[\mathrm{cGMP}]_{i}$ could arise from light-induced changes in the synthesis and/or degradation of cGMP; however, to date, characterization of light-dependent changes in $[\mathrm{cGMP}]_{i}$ in any invertebrate photoreceptors has been elusive (Brown et al., 1984a; Saibil, 1984; Johnson et al., 1986; Brown et al., 1992). Nonetheless, there is evidence for the presence of guanylate cyclase and of phosphodiesterase in invertebrate photoreceptors (Robinson and Cote, 1989; Inoue et al., 1992; Schraermeyer et al., 1993; Yoshikawa et al., 1993). Furthermore, there is recent evidence for cGMP induced excitation (Bacigalupo and O'Day, unpublished observations) and a cGMP-gated channel in Drosophila retina (Baumann et al., 1994).

In the present work, we have used an electrophysiological and pharmacological approach to investigate the hypothesis that cGMP metabolism is involved in light- and PI-induced excitation. Our results indicate that excitation can be modified by inhibitors of cGMP degradation in a $\mathrm{Ca}^{2+}$-dependent fashion. These results support the idea that excitation is dependent on cGMP metabolism, modulated by $\mathrm{Ca}^{2+}$ released during excitation.

Some of these results have appeared in abstract form (O'Day et al., 1991; Johnson and O'Day, 1992).

\section{Materials and Methods}

Preparation. Limulus polyphemus were obtained from Marine Biological Labs, Woods Hole, MA. Ventral nerves were removed, desheathed, and treated with pronase. The dissection and preparation of the ventral photoreceptors were similar to those described previously (Lisman et al., 1982) as were the electrical recording, extracellular superfusion, ion substitution, current-clamp, and voltage-clamp procedures.

Solutions. During dissection, desheathing, and impalement, the tissue was bathed in artificial seawater (ASW), in mM: $425 \mathrm{NaCl}, 10 \mathrm{KCl}, 22$ 
$\mathrm{MgCl}_{2}, 26 \mathrm{MgSO}_{4}, 10 \mathrm{CaCl}_{2}, 15 \mathrm{TrisCl}, \mathrm{pH} 7.8$. "1 $\mathrm{mM} \mathrm{Ca}^{2+}$ saline" indicates that only $1 \mathrm{~mm} \mathrm{CaCl} 2$ was added and $\mathrm{MgCl}_{2}$ was substituted mole-for-mole for $\mathrm{CaCl}_{2}$. The $\mathrm{Ca}^{2+}$ injection microelectrodes contained $10 \mathrm{~mm}$ Ca-aspartate, $100 \mathrm{~mm} \mathrm{~K}$-aspartate, $10 \mathrm{~mm}$ HEPES, pH 7.0. The $\mathrm{IP}_{3}$-injection electrodes contained $100 \mu \mathrm{M} \quad \mathrm{IP}_{3}$ [D-myo-inositol$(1,4,5)$ trisphosphate $\left(\mathrm{IP}_{3}\right)$ (Calbiochem)], $100 \mathrm{mM} \mathrm{K}$-aspartate, $10 \mathrm{~mm}$ HEPES, pH 7.0. Microelectrodes from which $\mathrm{Ca}^{2+}$-BAPTA mixtures were injected contained $100 \mathrm{mM} \mathrm{K}$-aspartate, $10 \mathrm{~mm}$ HEPES, $75 \mathrm{~mm}$ BAPTA, pH 7.0; Ca-aspartate was added to attain desired levels of free [C.a ${ }^{2+}{ }_{i}$ ]. A Ca-aspartate/BAPTA ratio, $R_{\text {CaRAPTA }}$, of 0.085 yields $10^{-8} \mathrm{M}$ $\mathrm{Ca}_{\text {free }}^{2} ; \mathrm{R}_{\text {Ca/BAPTA }}=0.48$ yields $10^{-7} \mathrm{M} \mathrm{Ca}^{2}$ free $; R_{\text {CaAAPTA }}=0.625$ yields $2.3^{*} 10^{-7} \mathrm{M} \mathrm{Ca}^{2}$ free $; R_{\text {Ca/BAPTA }}=0.90$ yields $10^{-6} \mathrm{M} \mathrm{Ca}_{\text {free }}^{2} ; R_{\text {Ca/BAPTA }}=$ 0.99 yields $10^{-5} \mathrm{M} \mathrm{Ca}^{2}$ frec $) . \mathrm{Ca}^{2+} / \mathrm{BAPTA}$ mixtures were injected until the cell no longer adapted to light at its new level of sensitivity. At $10^{-8} \mathrm{M} \mathrm{Ca}_{\text {free }}^{2}$, response kinetics were very slow, amplitudes were greatly decreased, and the effects of IBMX were inconsistent. IBMX (Sigma) was solubilized in ethanol before addition to experimental salines; the final ethanol concentration in IBMX and control salines was $0.1 \%$ in these experiments. Zaprinast (M\&B22948) was dissolved in triethanolamine before addition to experimental salines; the final triethanolamine concentration in zaprinast test saline and control salines was $0.1 \%$ in these experiments. Concentrations of zaprinast $(60 \mu \mathrm{M})$ and IBMX (1$2.5 \mathrm{~mm}$ ) were chosen to strike a balance between maximal effective PDE-inhibition and minimal effects of solvents. The selectivity and potency $\left(K_{i} \sim 150 \mathrm{nM}\right)$ of zaprinast is substantially greater than other PDE inhibitors (IBMX $K_{i} \sim 100 \mu \mathrm{M}$ ) against vertebrate photoreceptor PDE and other PDEs (Gillespie and Beavo, 1989). In all experiments reported, the concentration of PDE inhibitor in the vicinity of the cells' transduction apparatus is unknown. Under the conditions of our experinnents, physiological responses recorded in ethanol and triethanolamine control solutions were identical to those in normal bathing saline.

Optics. Illumination intensities shown in this paper are given in neutral density units (ND); each ND corresponds to a tenfold change in light intensity with 0 ND corresponding to the maximum available intensity, $1.0 \mathrm{~mW} / \mathrm{cm}^{2}$; white light was used (Osram Xenophot hlx64625 filament bulb). In dark-adapted cells, approximately one quantum bump per second was evoked with dim illumination of intensity -6.9 ND.

\section{Results}

PDE inhibitors induced small depolarization of dark membrane potential and induced small dark currents

PDE inhibitors have small effects on resting potential and/or dark currents in Limulus photoreceptors (Wulff, 1973; Corson et al., 1979; Yoshioka et al., 1983; Brown et al., 1984a). Because the present work concerns principally the cGMP specific PDE inhibitor, zaprinast (Gillespie and Beavo, 1989), we compared the effects of zaprinast on dark currents with those of IBMX. In photoreceptors voltage clamped to $-70 \mathrm{mV}$ in the dark, small inward currents were induced by zaprinast or IBMX; $60 \mu \mathrm{M}$ zaprinast induced a dark inward current $i_{\mathrm{dk}}=-0.24 \mathrm{nA} \pm 0.28$ $\mathrm{nA}(\mathrm{av} \pm \mathrm{SD} ; n=6)$. IBMX $(2.5 \mathrm{mM})$ induced $i_{\mathrm{dk}}=-0.49$ $\mathrm{nA} \pm 0.44 \mathrm{nA}$ (av $\pm \mathrm{SD} ; n=21$ ). The dark inward currents developed gradually $\left(\tau_{\text {on }} \sim 5 \mathrm{sec}\right)$. The effects of both IBMX and zaprinast were fully reversible at these concentrations.

\section{Effects of PDE inhibitors on light responses were intensity dependent}

PDE inhibitors cause a small reduction of the amplitudes of responses to dim test flashes in Limulus and other invertebrate photoreceptors (Wulff, 1973; Corson et al., 1979; Yoshioka et al., 1983; Brown et al., 1984a). IBMX (1 mM) reduced test flash response amplitudes by $0.36 \pm 0.26(n=4) \log _{10}$ units in normal saline and by $0.32 \pm 0.27(n=5) \log _{10}$ units in low $\mathrm{Ca}^{2+}$ saline. Similarly, zaprinast had only small effects on responses to dim test flashes (Fig. 1A). Test flashes of -4.3 ND presented at regular intervals evoked similar responses in the presence of $60 \mu \mathrm{M}$ zaprinast to those evoked in its absence. Similarly, zaprinast had only small effects on light response waveforms, amplitudes, and kinetics in low- $\mathrm{Ca}^{2+}$ saline.
A

Normal saline

Low-Ca saline
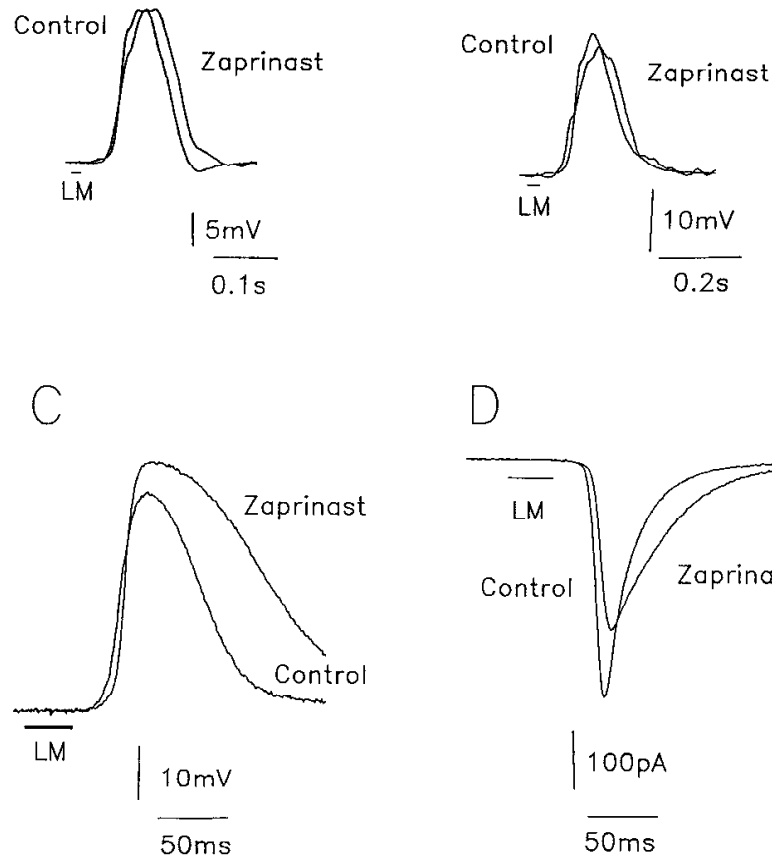

D

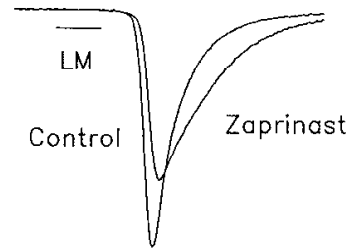

$100 \mathrm{pA}$

$\overline{50 \mathrm{~ms}}$

Figure 1. Effects of cGMP-PDE inhibitor, zaprinast, on electrical responses to brief test light flashes. $A$, Cells current clamped to dark $V_{m}$ of $-70 \mathrm{mV}$ were illuminated with a dim test flash $(-4.3 \mathrm{ND}, 25 \mathrm{msec})$ every $10 \mathrm{sec}$. Responses to two such flashes are shown superimposed: one before and one $15 \mathrm{~min}$ after introduction of $60 \mu \mathrm{M}$ zaprinast to normal $\mathrm{Ca}^{2+}(10 \mathrm{~mm})$ saline. Zaprinast had only a small apparent effect on response waveforms and amplitudes. The bars ( $L M$, light monitor) adjacent to the traces indicate the period of illumination. Similar results were observed in 6 of 6 cells. $B$, Zaprinast had a similar effect on dim test flash responses in $1 \mathrm{mM} \mathrm{Ca}^{2+}$ saline in 6 of 6 cells. $C$, Responses to bright test flashes $(-2.3 \mathrm{ND}, 50 \mathrm{msec})$ were slowed in onset and duration after introduction of $60 \mu \mathrm{M}$ zaprinast to normal $\mathrm{Ca}^{2+}$ saline. Superimposed traces compare current-clamp responses (resting potential $=-70 \mathrm{mV}$ ) obtained during and after zaprinast superfusion. Time constants for response recovery were $\tau_{\text {off }}$ (control) $=65 \mathrm{msec}$ and $\tau_{\text {off }}$ (zaprinast) $=130 \mathrm{msec}$. Similar results were observed in 5 of 6 cells. $D$. Similar response slowing occurred under voltage clanup (holding potential $=-70 \mathrm{mV}$ ). Zaprinast increased the total light-induced charge flow (time integral of the light-induced current) by $24 \%$ in this cell. The time constants for response recovery were $\tau_{\text {off }}$ (control) $=55 \mathrm{msec}$ and $\tau_{\text {orf }}$ (zaprinast) $=87 \mathrm{~ms}$. Following removal of zaprinast, light-induced currents returned to nearly the same values measured before zaprinast introduction.

In contrast, PDE-inhibitors had large effects on responses to bright test flashes. A retardation of the response kinetics was apparent when cells were current clamped in the presence of zaprinast (Fig. 1C). Bright lights induce large receptor potentials that trigger voltage-activated events. Thus, to examine the effects of PDE-inhibitors on transduction, rather than voltage-activated processes, we used voltage clamp to $-70 \mathrm{mV}$, where voltage-gated channels remain closed (Lisman et al., 1982). In these experiments, the kinetics of membrane currents evoked by brief, bright test flashes were retarded by $60 \mu \mathrm{M}$ zaprinast (Fig. $1 D$ ); kinetics both of response activation and of response rccovery were retarded. While peak response amplitudes were reduced by $60 \mu \mathrm{M}$ zaprinast, the total light-induced charge flow was elevated. Generally, we observed small changes in the peak 
A
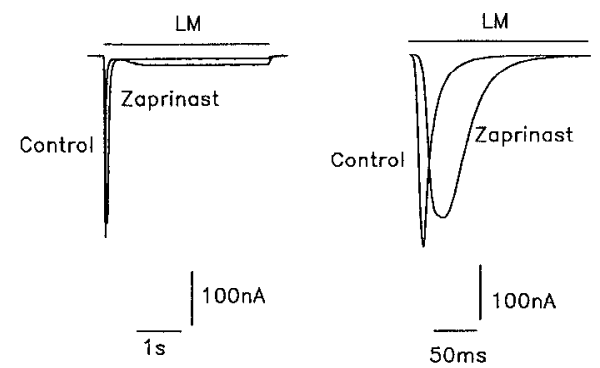

C

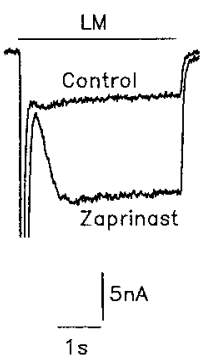

Figure 2. Effects of zaprinast on responses to prolonged illumination. Similar results to those in Figure 1 were obtained in experiments using prolonged stimulus duration. The cell was voltage clamped to $-70 \mathrm{mV}$ and presented with a -2.0 ND prolonged light stimulus. Responses during and after superfusion with $60 \mu \mathrm{M}$ zaprinast are superimposed for comparison. $A-C$ illustrate different aspects of the same response. $A$, The characteristic transient and plateau phases induced by prolonged bright illumination were altered by zaprinast exposure. The total lightinduced charge flow was increased $155 \%$ by zaprinast in this cell. The time constants for response recovery were $\tau_{\text {off }}$ (control) $=55 \mathrm{msec}$ and $\tau_{\text {off }}$ (zaprinast) $=87 \mathrm{msec} . B$, The same data are replotted, with an expanded time scale, to highlight the changes in response kinetics during the transient and deactivation phases. The response onset was delayed, and the transient component was prolonged after introduction of zaprinast. $C$, Same data are replotted with expanded vertical scale to highlight changes in response amplitudes during the plateau phase. Zaprinast greatly enhanced the amplitude of the plateau phase and the total lightinduced charge flow. The ratio of plateau amplitudes (zaprinast/control) was 3.01. Response recovery, the decline from plateau after stimulus termination, was not slowed. Similar results were observed in 7 of 7 cells.

amplitudes of light responses, but zaprinast invariably induced a significant increase in the net charge flow per response.

Zaprinast also slowed responses to prolonged illumination (Fig. 2). In control saline, voltage-clamp responses to bright illumination consist of a large transient inward current that declines to a much smaller maintained inward current (plateau phase). At the end of stimulation, recovery occurs: the current declines towards baseline (Millecchia and Mauro, 1969). Zaprinast increased the amplitudes of transient and plateau phases and the total charge flow during each response. The decline from the transient phase was slowed. However, unlike the effect on brief responses, the rate of recovery was unchanged. The effects of zaprinast on responses to test flashes (Fig. 1) and prolonged stimuli (Fig. 2) were fully reversed following return to control conditions.

A plot of the dependence of the effects of zaprinast on the intensities of the light stimuli is shown in Figure 3. The left hand panel illustrates the intensity dependence of zaprinast effects on the amplitudes of test flash responses. The right hand panel illustrates the intensity dependence of the prolongation of response kinetics by zaprinast. The effects of zaprinast were markedly enhanced when extracellular $\mathrm{Ca}^{2+}$ was lowered.

\section{Effects of PDE-inhibitor on bright light responses were $\mathrm{Ca}^{2+}$ dependent}

We compared the effects of PDE inhibitors on light responses evoked in low extracellular $\mathrm{Ca}^{2+}$ saline with those evoked in normal saline. Figure $4 A$ illustrates that, when $60 \mu \mathrm{M}$ zaprinast was introduced in low $\mathrm{Ca}^{2+}$ saline, the amplitudes of responses to bright test flashes were dramatically increased, contrasting with the effects in normal $\mathrm{Ca}^{2+}$ saline (Fig. $1 D$ ). Additionally,
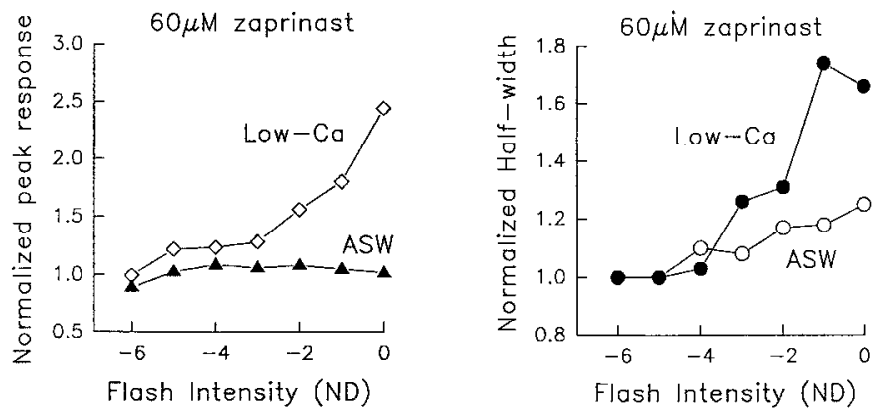

Figure 3. Effects of zaprinast on responses to various intensity stimuli. Intensity-response curves are shown from experiments similar to Figure 1 employing a series of test flash intensities. The left is a plot of normalized peak responses (peak) versus test flash $(25 \mathrm{msec})$ intensity for normal and low $\mathrm{Ca}^{2+}$ salines. Normalized peak response is the ratio of the peak current measured during superfusion in zaprinast saline to that in control saline. This illustrates the $\mathrm{Ca}^{2+}$ dependent response enhancement by zaprinast. The right is a plot of the ratio of the half-width (response duration measured at half-maximal amplitude) of the lightinduced currents measured during superfusion in zaprinast saline to that in control saline (normalized half-width). The results illustrate the retardation of response kinetics by zaprinast, and its enhancement in low$\mathrm{Ca}^{2+}$ saline.

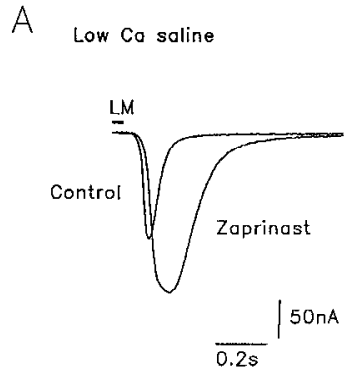

B Low co saline
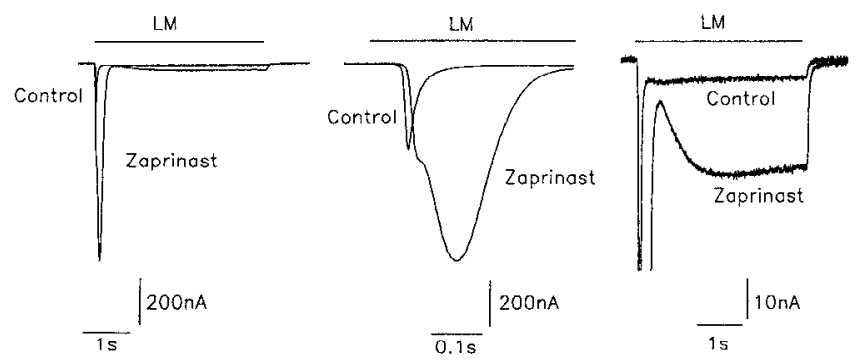

Figure 4. Effects of zaprinast after reducing extracellular $\mathrm{Ca}^{2+}$. Protocols identical to those in Figures 1 and 2 were used to examine the effects of zaprinast in low $(1 \mathrm{mM}) \mathrm{Ca}^{2+}$ saline. $A$, Voltage-clamp responses to bright test flashes were slowed and enhanced by $60 \mu \mathrm{M}$ zaprinast in $1 \mathrm{~mm} \mathrm{Ca}{ }^{2+}$ saline. The total light-induced charge flow was enhanced $269 \%$ by zaprinast introduction. Time constants for response recovery were $\tau_{\text {off }}$ (control) $=35.7 \mathrm{msec}$ and $\tau_{\text {off }}$ (zaprinast) $=103 \mathrm{msec}$. $B$, Responses to prolonged illumination were also slowed and enhanced by $60 \mu \mathrm{M}$ zaprinast. As in Figure 2, results have been replotted on an expanded time scale (middle) and an expanded vertical scale (right). Zaprinast enhanced and slowed the transient phase. The ratio of plateau amplitudes (zaprinast/control) was 3.74. The total charge flow in the zaprinast-low- $\mathrm{Ca}^{2+}$ record was $599 \%$ of the control-low-Ca ${ }^{2+}$ record. $L M$, Light monitor. Similar results were observed in 7 of 7 cells. 

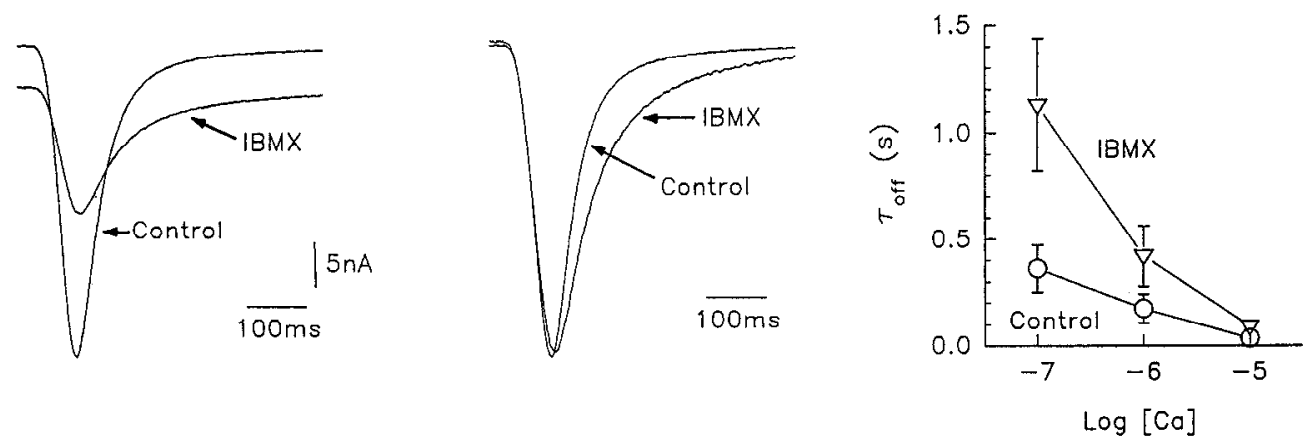

Figure 5. Effects of IBMX on response recovery times, $\tau_{\text {off }}$, in $\mathrm{Ca}^{2+} / \mathrm{BAPTA}$-injected cells. Injection of $\mathrm{Ca}^{2+} / \mathrm{BAPTA}^{\mathrm{B}}$ mixtures altered the time courses of test flash responses such that recovery occurred with a single exponential with time constant, $\tau_{\text {off }}$. Introduction of IBMX increased $\gamma_{\text {off }}$. Left traces show light-induced currents evoked in $2.5 \mathrm{mM}$ IBMX-saline and control saline, superposed to illustrate the slowing of the response recovery phase, and the difference in their resting current levels. The cell had been previously injected with $\mathrm{Ca}^{2+} / \mathrm{BAPTA}^{2}$ mixture of 0.625 (calculated microelectrode $\left[\mathrm{Ca}^{2+}{ }_{\text {free }}\right]=0.23 \mu \mathrm{M}$ (see methods). The middle traces show the same data normalized for clearer illustration of response slowing. At the right, the effects of $2.5 \mathrm{mM} \mathrm{IBMX}$ in $\left[\mathrm{Ca}^{2+}{ }_{\mathrm{i}}\right]$-stabilized cells on $\tau_{\text {off }}$ are plotted as a function of the calculated $\mathrm{Ca}^{2+}$ concentration in the injecting microelectrode. IBMX induced a large increase in $\tau_{\text {urr }}$ The effect was greatest in cells injected with the lowest Ca ${ }^{2+} / \mathrm{BAPTA}^{2}$ ratio, corresponding to $0.01 \mu \mathrm{M}\left[\mathrm{Ca}^{2+}{ }_{\text {free }}\right]$. Similar results were observed in $26 / 26$ cells that recovered fully following removal of IBMX.

zaprinast slowed test flash response kinetics to a much greater extent in low $\mathrm{Ca}^{2+}$ saline than it did in normal saline. Zaprinast also enhanced responses to prolonged light stimuli in low $\mathrm{Ca}^{2+}$ saline (Fig. 4B). The transient and plateau phases of the response were enhanced to a much greater extent in low $\mathrm{Ca}^{2+}$ than in normal $\mathrm{Ca}^{2+}$ saline ( $c f$. Fig. 2). The effects of zaprinast were fully reversible.

The $\mathrm{Ca}^{2+}$-dependent effects of PDE-inhibitors are elucidated
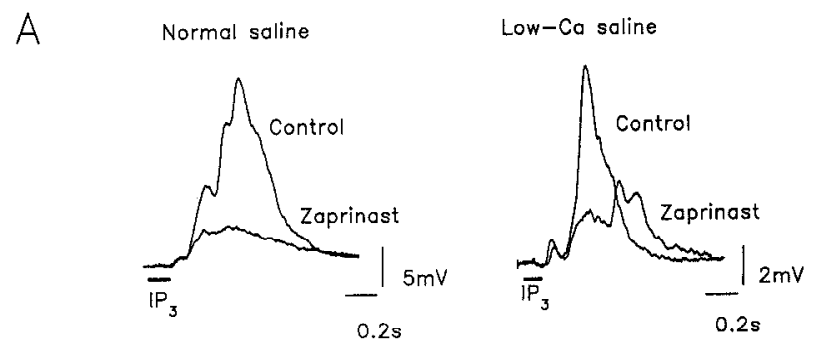

B

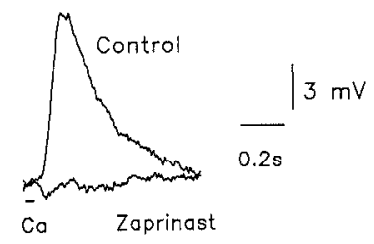

Figure 6. Effects of zaprinast on excitation induced by $\mathrm{IP}_{3}$ or $\mathrm{Ca}^{2+}$. $A$, Superimposed responses to $\mathrm{IP}_{3}$-injection pulses during exposure to $60 \mu \mathrm{M}$ zaprinast and after recovery in normal saline are shown. Zaprinast reduced the amplitude and slowed responses. Similar results were observed with normal and $1 \mathrm{mM} \mathrm{Ca}{ }^{2+}$ saline. Similar effects of IBMX on $\mathrm{IP}_{3}$-induced excitation were obtained in 3 of 3 cells. $\boldsymbol{B}$, Superimposed records of the response to pressure injection of calcium aspartate during exposure to $60 \mu \mathrm{M}$ zaprinast and after recovery. Zaprinast reduced the amplitude and slowed the response. Similar effects were observed in normal and $1 \mathrm{mM} \mathrm{Ca}^{2+}$ saline. Similar effects of IBMX on excitation induced by calcium injection were obtained in 4 of 4 cells. Effects of zaprinast in $A$ and $B$ were fully reversible. To establish that an injection of $\mathrm{IP}_{3}$ or calcium was successful, we required that injections induce substantial light-adaptation, as monitored by responses to test flashes test flashes presented before and after the injection pulse. in experiments with cells injected with $\mathrm{Ca}^{2+}$-buffer to stabilize $\left[\mathrm{Ca}^{2+}{ }_{i}\right]$ (Fig. 5). Injections of $\mathrm{Ca}^{2+}$-buffers alter light response amplitude and kinetics (Lisman and Brown, 1975; Frank and Fein, 1991; Shin et al., 1993), demonstrating the importance of $\mathrm{Ca}^{2+}$ and $\left[\mathrm{Ca}^{2+}{ }_{\mathrm{i}}\right]$ changes in normal physiology. We found that when cells were injected with mixtures of $\mathrm{Ca}^{2+}$-BAPTA, the recovery phases of currents induced by brief flashes could be fitted by an exponential with a single time constant, $\tau_{\text {off }}$ (Fig. 5 , center). When $2.5 \mathrm{mM}$ IBMX was introduced, the $\tau_{\text {urr }}$ was dramatically increased as response recovery slowed. Repeating the experiment with various $\mathrm{Ca}^{2+}$ /BAPTA mixtures (Fig. 5, right) illustrated that the increase in $\tau_{\text {off }}$ was strongly dependent on the level of $\left[\mathrm{Ca}^{2+}{ }_{\mathrm{i}}\right]$ (see Materials and Methods). The effects of IBMX were completely reversible.

\section{$I P_{3}$-induced and $\mathrm{Ca}^{2+}$-induced excitation were inhibited by zaprinast}

$\mathrm{IP}_{3}$-injection and $\mathrm{Ca}^{2+}$-injection mimic light-induced excitation in Limulus photoreceptors (Brown et al., 1984b; Fein et al., 1984; Payne et al., 1985). To examine whether cGMP metabolism might be linked to this artiticial excitation we studied the effect of zaprinast on excitation induced by injection of $\mathrm{IP}_{3}$ and on that induced by injection of $\mathrm{Ca}^{2+} ; 60 \mu \mathrm{M}$ zaprinast reversibly inhibited excitation induced by $\mathrm{IP}_{3}$-injection (Fig. $6 A$ ). Zaprinast also reversibly inhibited excitation induced by $\mathrm{Ca}^{2+}$-injection (Fig. 6B). Similar inhibition by zaprinast was observed in low$\mathrm{Ca}^{2+}$ saline. The effects of zaprinast were fully reversible.

\section{Discussion}

Our results indicate that the PDE inhibitors modify excitation in a $\mathrm{Ca}^{2+}$-dependent fashion. Enhancement of excitation by zaprinast was greatest in low $\mathrm{Ca}^{2+}{ }_{\mathrm{o}}$. However, excitation by dim light was not substantially affected by zaprinast, and excitation induced artificially by $\mathrm{IP}_{3}$-injection or by $\mathrm{Ca}^{2+}$ injection were inhibited by zaprinast. The slowing of response recovery was prolonged by IBMX in low $\left[\mathrm{Ca}^{2+}{ }_{\mathrm{i}}\right]$-stabilized cells. The results suggest that excitation is influenced by $\mathrm{Ca}^{2+}$-dependent cGMP metabolism.

Since cGMP opens light-activated membranc channcls (Bacigalupo et al., 1991), and since excitation involves PI pathway related $\mathrm{Ca}^{2+}$-release (Brown and Rubin, 1984; Payne et al., 1986), we have suggested (O'Day et al., 1991) that $\mathrm{Ca}^{2+}$ may 
serve to link the PI pathway with cGMP turnover to yield excitation. Our results support the idea (Corson et al., 1979; O’Day, 1991; Shin et al., 1993) that invertebrate transduction involves modulation of cGMP metabolism by $\mathrm{Ca}^{2+}$. Specifically, light-induced $\left[\mathrm{Ca}^{2+}{ }_{i}\right]$ mobilization may alter cGMP-PDE and/or guanylate cyclase activity to effect a transient rise in cGMP near the light-activated channels. We had proposed that $\mathrm{Ca}^{2+}$ inhibits both guanylate cyclase and cGMP-PDE with different affinities; $\mathrm{Ca}^{2+}$ mobilized by light inhibits first the cGMP-PDE, elevating [cGMP], and then the guanylate cyclase, rendering the [cGMP] elevation transient. The report of a light-dependent decline in cGMP-PDE activity supports this idea (Inoue et al., 1992). To maintain dark cGMP levels low, a vigorous dark cGMP-PDE activity would be required when guanylate cyclase is active. This could account for the small dark current induced by zaprinast, similar to vertebrate photoreceptors, which possess endogenous cGMP-PDE activity sufficiently vigorous to overwhelm artificially inhibited cGMP-PDE activity or elevated [cGMP] ${ }_{i}$ levels (Yau and Nakatani, 1985; Cervetto and McNaughton, 1986; Sather and Detwiler, 1987). While the present results support this model, our knowledge of intracellular chemistry is insufficient to make a conclusive characterization of zaprinast action or of interactions between the phosphoinositide and cGMP metabolic pathways.

Analyzing the $\mathrm{Ca}^{2+}$-dependence of zaprinast action is difficult because the instantaneous levels of $\mathrm{Ca}^{2+}$ have complex dependencies on $\mathrm{Ca}^{2+}$-exposure and on light. Exposure to low$\mathrm{Ca}^{2+}$ saline reduces dark levels of $\left[\mathrm{Ca}^{2+}{ }_{\mathrm{i}}\right]$ (Levy and Fein, 1985; O'Day and Gray-Keller, 1989) and elevates photoreceptor sensitivity (Lisman and Brown 1972); but prolonged low-Ca ${ }^{2+}$ exposure in the dark does not deplete intracellular $\mathrm{Ca}^{2+}$ stores (Bolsover and Brown, 1985; O'Day and Johnson, 1992). Thus, after a few minutes exposure to low- $\mathrm{Ca}^{2+}$ saline, the photoreceptor is very sensitive, and so the cell responds to bright light with a large receptor potential and a supernormal $\left[\mathrm{Ca}^{2+}{ }_{\mathrm{i}}\right]$ elevation. The enhanced $\left[\mathrm{Ca}^{2+}{ }_{i}\right]$ elevation persists throughout the response and recovery. This implies that zaprinast-induced response enhancement occurred when instantaneous $\left[\mathrm{Ca}^{2+}{ }_{i}\right]$ was high (Figs. $1 C, D, 2$ ); and zaprinast had very little effect at low instantaneous $\left[\mathrm{Ca}^{2+}{ }_{i}\right.$ ] (Fig. $1 A, B$ ). It is not clear, however, whether the $\mathrm{Ca}^{2+}$-dependent effects of zaprinast are governed by instantaneous $\left[\mathrm{Ca}^{2+}{ }_{i}\right]$ or by preexisting $\left[\mathrm{Ca}^{2+}{ }_{\mathrm{i}}\right]$.

Cells preloaded with $\mathrm{Ca}^{2+} / \mathrm{BAPTA}$ mixtures $\left(\left[\mathrm{Ca}^{2+}{ }_{\mathrm{i}}\right]\right.$-stabilized cells) show single exponential response recovery, suggesting a single process governing ligand removal near the lightsensitive channels under these conditions. The observation that IBMX retarded response recovery while maintaining its single exponential nature suggests that the underlying processes are IBMX sensitive. The $\mathrm{Ca}^{2+}$-dependence of $\tau_{\text {of }}$ supports the idea that response recovery involves $\mathrm{Ca}^{2+}$-sensitive cGMP metabolism.

Involvement of guanylate cyclase in transduction is supported by the recent description of a guanylate cyclase $\beta$-subunit gene in Drosophila retina (Yoshikawa et al., 1993). The $\mathrm{Ca}^{2+}$-dependent inhibition of light responses by cyclase inhibitor, imidodiphosphate (Bolsover and Brown, 1982), suggests that guanylate cyclase would be affected by light-induced changes in $\left[\mathrm{Ca}^{2+}{ }_{i}\right]$. There is evidence for other $\mathrm{Ca}^{2+}$-dependent enzymes involved in excitation that may influcnec cGMP metabolism and excitation (Edwards et al., 1995).

The inhibition of $\mathrm{IP}_{3}$ - and $\mathrm{Ca}^{2+}$-induced excitation by zaprinast (Fig. 6) suggests that there are inherent differences between light-induced excitation and $\mathrm{IP}_{3}-$ or $\mathrm{Ca}^{2+}$-induced excitation. This supports the notion that parallel excitatory pathways mediate transduction (Payne and Fein, 1986; Frank and Fein, 1991; Faddis and Brown, 1992; Shin et al., 1993). The observation that zaprinast affected bright light responses differently than dim light or chemically induced responses is similar to observations with PI pathway inhibitors (Lisman and Brown, 1975; Frank and Fein, 1991; Faddis and Brown, 1993; Shin et al., 1993). Thus, a simple linear model in which all the effects of light on excitation could be mediated through $\mathrm{IP}_{3}$-induced $\mathrm{Ca}^{2+}$-release seems inadequate. cGMP metabolism may be important at an earlier step in transduction in addition to a role in regulating levels of channel ligand.

A common feature of responses to bright prolonged illumination is the "dip" in the current trace between the transient and plateau phases (Figs. 2, 4). The origin of this dip is not understood, although it has been suggested that there are separate excitation pathways that separately yield the transient and plateau phases (Frank and Fein, 1991; Nagy, 1991). In this case the dip may mark the interval between light-induced activation of these separate excitation pathways. In any case, it is apparent that the "instantaneous sensitivity" $\left(S_{i}=\right.$ instantaneous lightinduced current per incident photon), which follows the current trace exactly since intensity is constant, increases substantially during transition from transient to plateau phases in the presence of zaprinast (Figs. 2, 4). Thus, it is possible that PDE-inhibition influences the regulation of photoreceptor sensitivity.

The modest differences between the effects of IBMX and zaprinast may arise from differences in specificity, zaprinast being a relatively specific inhibitor of cGMP-PDE. IBMX may also affect cAMP-dependent processes in these photoreceptors (Battelle, et al., 1982; Brown et al., 1984a; O'Day and Lisman, 1985) or phosphatidylinositol phosphorylation (Yoshioka et al., 1983).

IBMX can affect dark currents by affecting voltage-gated currents (Kass and Renninger, 1988; O'Day and Phillips, 1991). In the present work, we have used a holding potential of $-70 \mathrm{mV}$ under voltage clamp, a potential at which all known voltagegated channels are closed (Lisman et al., 1982; Phillips et al., 1992). Thus, our observations are limited to effects of PDE inhibitors on the light-sensitive conductance(s).

Our results point to a central role for $\mathrm{Ca}^{2+}$ and cGMP in PIdependent invertebrate transduction. Further biochemical and physiological studies will be required to acquire a fuller understanding of the intracellular signaling chemistry.

\section{References}

Bacigalupo J, Johnson EC, Robinson PR, Lisman JE (1990) Second messengers in invertebrate phototransduction. In: Transduction in biological systems (Hidalgo C, Bacigalupo J, Jaimovich E, Vergara J, eds), pp 27-45. New York: Plenum.

Bacigalupo J, Johnson EC, Vergara C, Lisman JE (1991) Light-dependent channels from excised patches of Limulus ventral photoreceptors opened by cyclic GMP. Proc Natl Acad Sci USA 88:7938-7942.

Battelle B-A, Evans JA, Chamberlain SC (1982) Efferent fibers to $\mathrm{Li}$ mulus eyes synthesize and release octopamine. Science 216:12501252.

Baumann A, Frings S, Godde M, Seifert R, Kaupp UB (1994) Primary structure and functional expression of a Drosophila cyclic nucleotidegated channel present in eyes and antennae. EMBO J 13:5040-5050.

Bolsover SR, Brown JE (1982) Injection of guanosine and adenosine nucleotides into I.imulus ventral photoreceptor cells. J Physiol (Lond) 332:325-342.

Bolsover SR, Brown JE (1985) Calcium ion, an intracellular messenger of light adaptation, also participates in excitation of Limulus photoreceptors. J Physiol (Lond) 364:381-393. 
Brown JE, Rubin LJ (1984) A direct demonstration that inositol-trisphosphate induces an increase in intracellular calcium in Limulus photoreceptors. Biochem Biophys Res Commun 125:1137-1142.

Brown JE, Kaupp UB, Malbon CC (1984a) 3',5'-Cyclic adenosine monophosphate and adenylate cyclase in phototransduction by $\mathrm{Li}$ mulus ventral photoreceptors. J Physiol (Lond) 353:523-539.

Brown JE, Rubin LJ, Ghalayini AJ, Tarver AP, Irvine RF, Berridge MJ, and Anderson RE (1984b) Evidence that myo-inositol polyphosphate may be a messenger for visual excitation in Limulus photoreceptors. Nature 311:160-163.

Brown JE, Watkins DC, Malbon CC (1987) Light-induced changes in the content of inositol phosphate in squid Loligo pealei retina. Biochem J 247:293-297.

Brown JE, Faddis M, Combs A (1992) Light does not induce an increase in cyclic-GMP content of squid or Limulus photoreceptors. Exp Eye Res 54:403-410.

Cervetto L, McNaughton P (1986) The effects of phosphodiesterase inhibitors and lanthanum ions of the light-sensitive current of toad retinal rods. J Physiol (Lond) 370:91-109.

Corson DW, Fein A, Schmidt J (1979) Two effects of phosphodiesterase inhibitors in Limulus ventral photoreceptors. Brain Res 176:365368.

Edwards SC, O'Day PM, Herrera DC (1995) Characterization of protein phosphatases type 1 and type 2A in Limulus nervous tissue: their light regulation in the lateral eye and evidence of involvement in the photoresponse. Visual Neurosci, in press.

Faddis M, Brown IE (1992) Flash photolysis of caged compounds in Limulus ventral photoreceptors. J Gen Physiol 100:547-570.

Faddis M, Brown JE (1993) Intracellular injection of heparin and polyamines. J Gen Physiol 101:909-931.

Fein A, Payne R, Corson DW, Berridge MJ, Irvine RF (1984) Photoreceptor excitation and adaptation by inositol 1,4,5-trisphosphate. $\mathrm{Na}$ lure 311:157-160.

Feng J, Frank TM, Fein A (1991) Excitation of Limulus photoreceptors by hydrolysis-resistant analogs of cGMP and cAMP. Brain Res 552: 291-294.

Frank T, Fein A (1991) The role of the inositol phosphate cascade in visual excitation in invertebrate microvillar photoreceptors. J Gen Physiol 97:697-724.

Gillespie P, Beavo J (1989) Inhibition and stimulation of photoreceptor phosphodiesterases by dipyridamole and M\&B22,948. Mol Pharmacol 36:773-781.

Hardie RC, Minke B (1994) Novel $\mathrm{Ca}^{2+}$ channels underlying transduction in Drosophila photoreceptors: implications for inositide-mediated $\mathrm{Ca}^{2+}$ mobilization. Trends Neurosci 16:371-376.

Inoue M, Ackermann K, Brown JE (1992) Cyclic GMP phosphodiesterase in photoreceptor cells in Limulus ventral eye. In: Signal transduction in photoreceptor cells (Hargrave PA, Hofmann KP, Kaupp UB, eds), pp 271-280. Berlin: Springer.

Johnson EC, O'Day PM (1992) Effects of cyclic-GMP metabolism inhibitors on $\mathrm{IP}_{3}$-induced and $\mathrm{Ca}^{2+}$-induced excitation of Limulus photoreceptors. Biophys J 61:426a.

Johnson EC, Robinson PR, Lisman JE (1986) Cyclic GMP is involved in the excitation of invertebrate photoreceptors. Nature 324:468-470.

Kass I, Renninger GH (1988) Circadian changes in function of $\mathrm{Li}$ mulus ventral photoreceptors. Visual Neurosci 1:3-11.

Levy S, Fein A (1985) Relationship between light sensitivity and intracellular free Ca concentration in Limulus ventral photoreceptors. J Gen Physiol 85:805-841.

Lisman JE, Brown JE (1972) The effects of intracellular iontophoretic injection of calcium and sodium ions on the light response of Limulus ventral photoreceptors. J Gen Physiol 59:701-719.

Lisman JE, Brown JE (1975) Effects of intracellular injection of calcium buffers in Limulus ventral photoreceptors. J Gen Physiol 66: 489-506.
Lisman JE, Fain GL, O'Day PM (1982) Voltage-dependent conductances in Limulus ventral photoreceptors. J Gen Physiol 79:187-209.

Millecchia R, Mauro A (1969) The ventral photoreceptor cells of $\mathrm{Li}$ mulus III A voltage-clamp study. J Gen Physiol 54:331-351.

Nagy K (1991) Biophysical processes in invertebrate photoreceptor: recent progress and a critical overview based on Limulus photoreceptors. Q Rev Biophys 24:165-226.

O'Day PM (1991) Sodium-calcium exchange in invertebrate photoreceptors. Ann NY Acad Sci 639:285-299.

O'Day PM, Gray-Keller MP (1989) Evidence for electrogenic $\mathrm{Na}^{+} / \mathrm{Ca}$ exchange in Limulus ventral photoreceptors. J Gen Physiol 93:473492.

O’Day PM, Johnson EC (1992) Light-induced sensitization of Limulus ventral photoreceptors in low $\mathrm{Ca}^{2+}$ saline. Biophys $\mathrm{J}$ 61:520a.

O'Day PM, Lisman JE (1985) Octopamine enhances dark-adaptation in Limulus ventral photoreceptors. J Neurosci 5:1490-1496.

O'Day PM, Phillips CL (1991) Modulation of the voltage-dependent maintained potassium conductance in Limulus ventral photoreceptors. Biophys J 59:531a.

O'Day PM, Johnson EC, Baumgard M (1991) Effects of lithium, calcium, and PDE-inhibitors on excitation in Limulus photoreceptors. Biophys J 59:540a.

Payne R, Fein A (1986) The initial response of Limulus ventral photoreceptors to bright flashes: released calcium as a synergist to excitation. J Gen Physiol 87:243-269.

Payne R, Corson DW, Fein A (1985) Pressure injection of calcium both excites and adapts Limulus ventral photoreceptors. J Gen Physiol 88:101-112.

Payne R, Corson DW, Fein A, Berridge MJ (1986) Excitation and adaptation of Limulus ventral photoreceptors by inositol 1,4,5-trisphosphate result from a rise in intracellular calcium. J Gen Physiol 88:127-142.

Payne R, Walz B, Levy S, Fein A (1988) The localization of calcium release by inositol trisphosphate in Limulus photoreceptors and its control by negative feedback. Philos Trans R Soc Lond [Biol] 320: 359-379.

Phillips CL, Bacigalupo J, O'Day PM (1992) Inward rectification in Limulus ventral photoreceptors. Visual Neurosci 8:19-25.

Ranganathan R, Harris WA, Zuker CS (1991) The molecular genetics of invertebrate phototransduction. Trends Neurosci 14:486-493.

Robinson PR, Cote R (1989) Characterization of guanylate cyclase in squid photoreceptors. Visual Neurosci 3:1-7.

Saibil HR (1984) A light-stimulated increase in cyclic GMP in squid photoreceptors. FEBS Lett 168:213-216.

Sather W, Detwiler P (1987) Intracellular biochemical manipulation of phototransduction in detached rod outer segments. Proc Natl Acad Sci USA 84:9290-9294.

Schraermeyer U, Stieve H, Rack M (1993) Cyclic 3',5'-nucleotide phosphodiesterase: cytochemical localization in photoreceptor cells of the fly Calliphora erythrocephala. J Neurocytol 10:845-853.

Shin J, Richard EA, Lisman JE (1993) $\mathrm{Ca}^{2+}$ is an obligatory intermediate in the excitation cascade of Limulus photoreceptors. Neuron 11:845-855.

Wulff VJ (1973) The effect of cyclic AMP and aminophylline on $\mathrm{Li}$ mulus lateral eye retinular cells. Vision Res 13:2335-2344.

Yau K-W, Nakatani K (1985) Light-suppressible, cyclic GMP-sensitive conductance in the plasma membrane of a truncated rod outer segment. Nature 317:252-255.

Yoshikawa S, Miyamoto I, Aruga J, Furuichi T, Okano H, Mikoshiba K (1993) Isolation of a Drosophila gene encoding a head-specific guanylyl cyclase. J Neurochem 60:1570-1573.

Yoshioka T, Inoue H, Takagi M, Hayashi F, Amakawa T (1983) The effect of isobutylmethylxanthine on the photoresponse and phosphorylation of phosphatidylinositol in octopus retina. Biochim Biophys Acta 755:50-55. 